Wanda Świątkowska*

\title{
The Political Hamlet According to Jan Kott and Jerzy Grotowski ${ }^{1}$
}

\begin{abstract}
The article presents political interpretations of Hamlet in Poland in the turbulent period of politcal changes between the mid-1950s and mid-1960s. The author discusses the relationships between Shakespeare's tragedy and Polish political context as well as the influence of audience expectations in the specific interpretations. The selected performances are: Hamlet by Roman Zawistowski (at the Old Theatre in Cracow 1956) and Hamlet Study by Jerzy Grotowski (at the Laboratory Theatre of 13 Rows in Opole 1964). They both were hugely influenced by major commentators of Hamlet, i.e. Stanisław Wyspiański and Jan Kott. The author argues that up-to-date readings of Hamlet, which started with Wyspiański's study in 1905, flourished in the mid-1950s and mid-1960s when concerning specific political events: the Polish Thaw of 1956 and March 1968, when the Jews were expelled from Poland. Thus Hamlet of that time was updated and must be seen through the prism of political events.
\end{abstract}

Keywords: William Shakespeare, Stanisław Wyspiański, Jerzy Grotowski, Jan Kott, Hamlet, Hamlet Study, Polish Thaw of 1956, March 1968, politics.

This article looks at two interpretations of William Shakespeare's Hamlet and the concepts of updating the tragedy put forward by Jan Kott, and Jerzy Grotowski. It will not investigate their further professional relationship or Kott's attitude to Grotowski's later works. The article will only focus on one episode in their careers that took place in Poland in the period between the mid-1950s and mid-1960s.

In 1956 Jan Kott was a professor at the Faculty of Polish Studies at the University of Warsaw, while Grotowski had just finished his studies at the State Institute for Theatre Arts in Moscow (GITIS) and returned to Cracow to study directing at the State Drama School and work as a teaching assistant. Back then,

\footnotetext{
* Jagiellonian University in Cracow, Poland.

${ }^{1}$ This article is based on the paper delivered at the international conference "Jan Kott Our Contemporary: Contexts, Legacies, New Perspectives," which took place in Kingston-upon-Thames on 19 February 2015.
} 
Kott was forty-two years old, whereas Grotowski was only twenty-three, and he had just begun his artistic career. They did not know each other at that time yet.

Following the period of Stalin's regime, the Polish Thaw in October 1956 led to the temporary liberalization of the political system in Poland and to the increase in the country's autonomy from the Soviet Union. In theatre, the Thaw gave rise to more open discussions on contemporary issues and more vehement protests against the communist regime. Hamlet, which had only been staged three times after the Second World War, returned onto the Polish stage. In 1956, Roman Zawistowski directed the famous stage adaptation of the play at the Old Theatre in Cracow. It became famous, among other things, thanks to Kott's review entitled "Hamlet after the Twentieth Congress [of the Communist Party of the Soviet Union]." Kott underscored the political dimension of the production and stated that it was the most contemporary Hamlet he had ever seen. For Kott, the message of Zawistowski's 1956 Hamlet was "limited to one issue only. It was a political drama par excellence" (Shakespeare 53). The words "Denmark is a prison" meant for him, and for the audience as well, that "Poland was a prison." Zawistowski's Hamlet was set in "the Elsinore [where] Stalin's crimes were made public" (Kott, "Przedmowa" 9). Hamlet himself was "watched" and kept under surveillance because at Elsinore Castle, as Kott puts it, "someone is hidden behind every curtain" (Shakespeare 54). Hamlet was a prisoner of the totalitarian regime. Political crime and investigation, spying, deceit, fear, and conspiracy were, according to Jan Kott, the main themes of Zawistowski's production. "The Grand Mechanism" destroyed the innocent ones, like Ophelia. Played by Leszek Herdegen, the Hamlet of the Polish Thaw, was a "rebellious ideologist" (Kott, Shakespeare 61) who was deeply involved in politics. As Kott states, "Politics hangs here over every feeling, and there is no getting away from it. All the characters are poisoned by it" (Shakespeare 55).

Kott's political interpretation of Zawistowski's adaptation was so strong and persuasive that even now, many years later, this Hamlet is still called "Hamlet after the Twentieth Congress." This production marks the beginning of what Marta Fik calls the period of "Shakespeare in the theatre of [political] allusions" and metaphors (232), when Shakespeare's tragedies served as a mirror to the contemporary political situation in Poland. Jan Kott initiated this trend. His reviews of the productions of Shakespeare's plays made in the 1950s and 1960s gave rise to his book Shakespeare Our Contemporary, which offered an insightful commentary on the adaptation strategies used in these performances and exerted considerable influence on theatre in Poland and abroad. However, Kott was not the first one to treat Hamlet like "a sponge [that] immediately absorbs all the problems of our time" (Shakespeare 84). What is more, his explicitly political interpretations were sometimes imposed on the performances and unquestioningly accepted by directors, critics and members of the audience. 
Jerzy Grotowski saw Zawistowski's Hamlet as well and years later, in 1997, he recalled that "[t]his Hamlet was very conventional and had nothing to do with what Kott wrote about it" (qtd. in Osiński 158). According to Zbigniew Osiński, Grotowski further claimed that "[t]he audience gives the meaning to a performance" (158). To develop this statement further, it is possible to argue that what gives meaning to a performance is both the audience and the political context of the times. The political dimension of Zawistowski's Hamlet was not underlined or even mentioned in a few reviews. One critic wrote that the adaptation was "bright, simple, energetic and optimistic, and free from dark ambiguities" (Vogler 12). Sławomir Mrożek noted that the Danish prince was "a nice and straightforward man," "a boy who discovers the truth for his own use." He did not address the political dimension of the tragedy and its adaptation in any way.

In 1958 Grotowski published an essay on Leszek Herdegen's acting, in which he wrote that "In Hamlet Herdegen revealed his personal experience- his passions, philosophy and attitude to life" (103). According to Grotowski, Herdegen performed this role in a modern way. He maintained distance from his character and was somewhat cynical towards Hamlet. Although Grotowski criticized Herdegen's technical deficiencies: his shortness of breath, poor diction and physical fatigue, he called him "a humanist" who spoke on behalf of his generation (Grotowski 102-104).

It was Kott who added a political dimension to some of Shakespeare's plays that were staged at that time in Poland. In other words, he saw what he wanted to see. Later, Kott published a short version of his review of Zawistowski's Hamlet in the chapter entitled "Hamlet of the Mid-Century" (1965) in Shakespeare Our Contemporary, together with the reviews of other productions directed by Jakub Rotbaum (Wrocław, 1958) and Irena Babel (Warsaw, 1959). In this chapter, Kott slightly toned down his political interpretation of the stage adaptation.

Jerzy Grotowski staged his Hamlet eight years later. In 1964 he directed Hamlet Study at the Laboratory Theatre of 13 Rows in Opole. The performance was based on Shakespeare's tragedy and the study of Hamlet by Stanisław Wyspiański (1905). As has been mentioned, Jan Kott was not the first one to notice that Hamlet was "our contemporary." It was Stanisław Wyspiański who did so first. As Marta Gibińska explains,

When Kott in his review of the 1956 production of Hamlet at the Old Theatre in Cracow writes enthusiastically that it is the most political and the most contemporary Hamlet he has seen, that Elsinore is Poland and Hamlet reads current newspapers rather than books, he continues the critical thinking that Wyspiański formulated at the beginnings of this century. (184) 
She also stresses that

[a]fter 1956 most Shakespeare productions in Poland expressed the historical contemporaneity of the moment; this "temporalisation" sometimes more political and sometimes less was, surprisingly enough, carried out on Wyspiański's percept that Shakespeare embodies current Polish thinking. (Gibińska 184)

Stanisław Wyspiański was a poet, playwright and painter who lived in Cracow at the turn of the twentieth century. In 1905 he published the book entitled Hamlet, which is often called Hamlet Study and in which he wrote the following words: "In Poland Hamlet's riddle is: what is there in Poland-to think about" (Wyspiański 99; trans. Kraszewski 313). "What to think?"-asks Wyspiański, and immediately replies: "It depends on the reader and the circumstances in which the reader lives" (97, own translation). These words indicate that, as a dramatic character, Hamlet has played a significant role in Polish culture. They also suggest that our understanding of the tragedy needs to be constantly verified and adjusted to contemporary reality. In fact, for Wyspiański the Prince of Denmark was the Prince of Poland who walks around the Renaissance galleries at the Royal Castle in Cracow. For Wyspiański, Hamlet was a topical play that reflected the political situation of Poland and the actual problems of its citizens. The tragedy was, according to him, a mirror to Polish reality, theatre, art, history and identity. Long before Kott wrote Shakespeare Our Contemporary, Wyspiański pondered upon "Hamlet Our Contemporary."

Unlike in Goethe's famous interpretation, in Wyspiański's study Hamlet was depicted as a lonely hero, an intellectual who remains true to his beliefs and who keeps searching for the truth in spite of obstacles. Hardly a passive character, the protagonist undergoes a journey during which he meets his destiny and finds the truth about his fate, which coincides with his own death. Wyspiański states that "Hamlet does not hamletize [hesitate] - he thinks" (146, own translation), referring to the process of self-reflection that leads to spiritual growth and intellectual development. The protagonist's reflective nature is indicative of his humanity and self-awareness, rather than hesitation or indecision.

Polish intellectuals, especially in the times of political unrest, found themselves in the position of Wyspiański's Hamlet. They understood the ethos of "the Polish prince" very well. They identified themselves with his steadfastness, lonely struggle against the odds and his opposition to the system. Wyspiański's interpretation was powerful and had an immense impact on the twentieth-century Polish theatre. Hamlet Study was dedicated to "Polish actors," because Wyspiański perceived them as the conscience of the nation and those who approach contemporary reality in a critical way. The play was informed by Wyspiański's vision of a perfect theatre as a place of spiritual development and 
deep internal experience, where the truth can be found. Many Polish directors regarded Hamlet Study as their bible.

Charles Kraszewski argues that "Wyspiański's study of Hamlet is one of the most thoughtful and thorough critical works on Shakespeare's masterpiece written in Polish or English" (311). Jan Kott thought exactly the same. In 1959 his essay "Hamlet Wyspiańskiego" ("Hamlet by Wyspiański"), which offered a precise and insightful interpretation of Hamlet Study, appeared in the Polish magazine Dialog. In 1965 he included it in the Polish edition of Shakespeare Our Contemporary. In this essay, Kott presents Wyspiański as his ally and mentor, who was also a Polish pioneer in bringing Shakespeare up to date.

Grotowski highly valued Wyspiański's works. In 1962 at the Laboratory Theatre of 13 Rows, he staged Akropolis, which was based on Wyspiański's poetic drama, and in March 1964 he directed Hamlet Study, based both on Shakespeare's tragedy and Wyspiański's book. The latter did not follow the plot of the play-Grotowski cut out half of the characters and many important scenes. He rearranged the original dialogues and monologues and combined them with excerpts from Wyspiański's book. While working on the script, he followed the order of Wyspiański's commentaries and supplemented them with the corresponding fragments of Shakespeare's tragedy. Both source texts were treated in an innovative way-they were cut and rearranged. In the theatre programme, Ludwik Flaszen wrote:

We do not 'play' Hamlet - either as a classic Shakespearean version, or in accordance with the staging suggestions included in Wyspiański's famous essay, Hamlet Study. By using fragments of Shakespeare's play and Wyspiański's commentary, we give our own version of the Danish prince's story: variations on selected Shakespearean motifs. A study of a motif. (99)

That is why the title of the performance was Hamlet Study, rather than just Hamlet. Ludwik Flaszen explains that it was indeed as "a study of the acting method and of collective directing" (99). There was no one person who directed the performance. The poster featured an inscription: "Written and directed by Jerzy Grotowski's company." The performance was devised collectively: actors did their own research and were engaged in the further process of creation. The script was pieced together from their improvisations based on excerpts from Wyspiański's and Shakespeare's texts. Actors chose dialogues and monologues which were important to them. As Flaszen notes, "If a particular fragment did not stimulate the actors' and director's imagination, it was cut" (101).

Hamlet Study was staged on an empty stage, between two rows of seats, with the viewers facing one another. It was an example of Grotowski's "poor theatre." According to Flaszen, the poor theatre "us[es] the smallest amount of fixed elements to obtain maximum results[, and] create[s] complete worlds using only the things to hand. [...] The driving force behind it is certainly a living 
being, the actor" (93). Ultimately, what constituted the essence of the performance and served as its indispensable component were real people- the actor and the spectator. The additional elements (stage design, music, and lighting effects) were eliminated.

In Hamlet Study, the actors performed on a bare stage without elaborate props or scenery. The actors used chairs, garments, and a piece of cloth, or a blanket. All verbal and non-verbal sounds were created by them. The central element of the performance was the relationship between the actors and the audience. Furthermore, the empty stage communicated the universality and timelessness of Elsinore. This play could take place at any place and any time.

Grotowski did not use any historical costumes or stage design. Following Wyspiański's remarks, he rejected the traditional style of staging Shakespeare. He did not use expensive decorations or underscore the historical dimension of the play, and created an authentic theatrical space instead. While the events of Wyspiański's Hamlet took place at the Wawel Castle, Grotowski set his play in the Polish countryside. Performing on an empty stage, his actors created the auditory landscape of a Polish village, underscoring its literal and symbolic dimensions. The village was plunged in the atmosphere of inertia and powerlessness: the actors imitated the sound of a gust of wind and the cawing of crows, and they lamented and sang prayer songs.

Grotowski borrowed the idea of updating Shakespeare's drama from Wyspiański's work and set the play in the contemporary Polish context. The plot took place in a Polish village - the courtiers were Polish peasants and Hamlet was an intellectual whom they perceived as a stranger who belongs to a different world. To highlight this conflict, Grotowski presented Hamlet as a Jew. In the Poland of the 1960s, such a concept was controversial and provocative.

In his book Grotowski \& Company, Ludwik Flaszen recalls:

Our production, after long weaving and searching, became a sort of vision of the phenomenon of communist populism and its deep (not to say native, indigenous) sources - a vision of some archaic country of peasants and soldiers, with the lonely intellectual, Hamlet-Jew, excluded from the community of vigorous people [...] - the eternal problems of the Polish elite, alienated from the 'deep' country. (253)

Grotowski focused on the opposition between the mob, its cruelty of and raw stamina, and a helpless and weak human being. Flaszen called the two sides of this conflict "Practical Brawn and Theoretical Reason" (99). There was no hope for an agreement between these two parties - they lived in two worlds of different values. The brutal peasants mocked and persecuted the Jewish Hamlet. His efforts to ally himself with them were pointless and futile. Hamlet became a perfect example of the Other. His otherness, conspicuous in his white shirt, polished shoes and a book in his hands, provoked the crowd's hatred and 
emphasized the gap between him and the rest of the characters. He remained alone, alienated from the brutal and primitive peasants who represented the Polish nation.

In 1964 such an interpretation of Shakespeare's masterpiece was seen as an act of political rebellion. The premiere took place four years before the outburst of anti-Semitic demonstrations in 1968, when Polish authorities turned the dissatisfaction and aggression of the working class against Jews and the intelligentsia. For some critics, Hamlet Study clearly anticipated March 1968 (Morawiec 210) and it was certainly the most political of all Grotowski's productions. It proved to be prophetic and touched upon the problem of Polish anti-Semitism, which had remained deeply hidden after the Second World War, but had not disappeared. "There is always a need for the Jew to be beaten-and a need for the 'pogromer,' who absolves us from the abstract"-writes ruefully Ludwik Flaszen, a Jew himself (99).

Hamlet Study was staged only twenty times and, after one month, all further performances were cancelled. Very few reviews were published and very few photos of the production have survived. The Laboratory Theatre of 13 Rows knew that they had gone too far. Zygmunt Molik, who played Hamlet, stated that Hamlet Study had an all too explicit political message to be staged; Flaszen was afraid of being expelled from the country; Grotowski asked Eugenio Barba to bring him some cyanide from the West (Flaszen 255). They perfectly knew that the performance was perceived by the communist authorities as too radical and dangerous.

Under the guise of staging a well-known classic, the Laboratory Theatre of 13 Rows showed the ongoing conflicts and the antagonisms visible in Poland at that time. One critic stated that their Hamlet was "very contemporary and very Polish" (Mach 3). Although Jan Kott did not see Grotowski's production, he must have been aware of its political significance and subversive potential. The anti-semitic campaign of 1968 touched him personally. Back then he was a visiting professor at Berkley and he had no intention to return to Poland. In 1969, having been expelled from the University of Warsaw, he applied for political asylum in the USA. He decided to remain in exile and to work abroad. After thirteen years, Kott returned to Poland-just for a short visit. Like Grotowski's Jewish Hamlet, he was a victim of persecution.

Wyspiański, Kott and Grotowski updated Hamlet by making direct references to their own times. Wyspiański wrote his Hamlet for the Poles who lived in partitioned Poland, Kott reinterpreted Shakespeare's masterpiece when he saw a glimpse of hope for liberalization and political change in the Polish People's Republic, while Grotowski staged his Hamlet Study when the political atmosphere began to heat up again and his interpretation of Shakespeare's masterpiece was the most radical one. It anticipated the future events and uncovered the dangerous, anti-Jewish sentiment in Polish society. As Ludwik Flaszen puts it, "Hamlet Study was an indicator of the process that revealed itself 
fully in March 1968" (254). The interpretation was explicit and dangerously transparent and, therefore, the performance was only staged a few times. Years later, Grotowski seldom mentioned this production.

It follows from the above that, generally, Wyspiański, Kott and Grotowski thought about Hamlet in a similar manner. Each of them examined Shakespeare's tragedy in order to find a solution to contemporary problems of their nation and to diagnose the political situation of their country. They transformed the Danish prince into a Pole whose life is shaped by contemporary circumstances and who faces problems that Poland experienced in the given times. Each one of them wanted to extract some crucial, topical message from the old dramatic text in order to comment upon his own reality.

\section{WORKS CITED}

Fik, Marta. "Szekspir w teatrze aluzji." Od Shakespeare'a do Szekspira. Ed. Jan Ciechowicz and Zbigniew Majchrowski. Gdańsk: Centrum Edukacji Teatralnej, 1993. 232-243.

Flaszen, Ludwik. Grotowski \& Company. Trans Andrzej Wojtasik and Paul Allain. Ed. Paul Allain. Holstebro: ICARUS, 2010.

Gibińska, Marta "More than Jan Kott's Shakespeare-Shakespeare in Polish Theatre after 1956." On Page and Stage: Shakespeare in Poland and World Culture. Ed. Krystyna Kujawinska-Courtney. Kraków: Universitas, 2000. 183-196.

Grotowski, Jerzy. "Leszek Herdegen. Aktor publicystyczny." Współczesność 16 Dec. 1958: 8. Rpt. in Teksty zebrane. Ed. Agata Adamiecka-Sitek et al. Warszawa: Wydawnictwo Krytyki Politycznej, Instytut Teatralny im. Zbigniewa Raszewskiego, Instytut im. Jerzego Grotowskiego, 2012. 102-104.

Kott, Jan. "Przedmowa autora do drugiego wydania." Szekspir współczesny. Kraków: Wydawnictwo Literackie, 1997. 7-11.

—. Shakespeare Our Contemporary. Trans. Bolesław Taborski. New York: Double Day, 1964.

Kraszewski, Charles. "Stanisław Wyspiański as Proselytising Translator: National Directioning in his Polonisations of Hamlet and Le Cid." Canadian Slavonic Papers 35.3-4 (1993): 305-28.

Mach, Wilhelm. "Wiosna Opolska 1964.” Życie Warszawy 28-29 June 1964: 3.

Morawiec, Elżbieta. Powidoki teatru. Świadomość teatralna $w$ polskim teatrze powojennym. Kraków: Wydawnictwo Literackie, 1991.

Mrożek, Sławomir. "Dzień dobry Książę." Echo Krakowskie 15 Oct. 1956: n. pag. Encyklopedia Teatru Polskiego. 5 Mar. 2018. <http://www.encyklopediateatru. $\mathrm{pl} /$ artykuly/51136/dzien-dobry-ksiaze>.

Osiński, Zbigniew. Spotkania z Jerzym Grotowskim. Notatki, listy, studium. Gdańsk: słowo/obraz terytoria, 2013.

Vogler, Henryk. "Krakowski przyczynek do hamletologii." Teatr 15-30 Nov. 1956: 12-14. Wyspiański, Stanisław. "Hamlet." Dzieła zebrane. Ed. Leon Płoszewski. Vol. 13. Kraków: Wydawnictwo Literackie, 1961. 5-195. 